Історико-політичні проблеми сучасного світу: Збірник наукових статей. - Чернівці: Чернівецький національний університет, 2019. - T. 39. - C. 58-67

DOI: $10.31861 / \mathrm{mhpi} 2019.39 .58-67$
Modern Historical and Political Issues: Journal in Historical \& Political Sciences. - Chernivtsi: Chernivtsi National University, 2019. - Volume. 39. - pp. 58-67 DOI: $10.31861 / \mathrm{mhpi} 2019.39 .58-67$

UDC: $327:[622.32: 338.45](567=222.5: 560)$

(C) Qadir Aso Araz ${ }^{1}$

\title{
Iraqi Kurdistan Oil and Gas Sector: Iraqi and International Dimensions
}

The article deals with the problem of the influence of the Iraqi Kurdistan oil and gas industry on the relations of the Kurdish autonomy with the central authority of Iraq. The international aspects of extraction and transportation of hydrocarbons from the territory of the Kurdistan Region are also analyzed. The legal basis for the functioning of the oil and gas complex in the region, the main differences between Erbil and Baghdad regarding the powers of the Kurdish regional government in the field of exploitation of natural resources of the autonomy is represented.

It has been established that the independent activity of the Iraqi Kurdistan authorities in the development of the oil and gas industry in its territory, the wide involvement of foreign investment provided autonomy a significant source of income, which became the financial backing of Erbil in his political disputes with Baghdad. At the same time, in the question of the transportation of hydrocarbon, the landlocked Iraqi Kurdistan was critically dependent on Turkey, which greatly limits its range of options in its relations with Ankara. Excessive dependence of the Iraqi Kurdistan economy on hydrocarbon exports is one of the strategic challenges for Kurdish autonomy, but significant positive developments in this area are possible only in the long-term perspective.

Key words: Iraq, Iraqi Kurdistan, Kurdish autonomy, Turkey, oil and gas industry.

\section{Нафтогазовий сектор Іракського Курдистану: іракський та міжнародний виміри}

Розглянуто проблему впливу нафтогазової галузі Іракського Курдистану на відносини курдської автономії з центральною владою Іраку. Також проаналізовано міжнародні аспекти видобутку та транспортування вуглеводнів з території Регіону Курдистан. Показано правову основу функціонування нафтогазового комплексу регіону, головні розбіжності між Ербілем та Багдадом щодо повноважень курдського регіонального уряду у сфері експлуатації природних ресурсів автономії.

Встановлено, що самостійна діяльність влади Іракського Курдистану з розвитку нафтогазової галузі на своій території, широке залучення іноземних інвестицій надали автономії значне джерело власних доходів, що стало фінансовою опорою Ербілю у його політичних суперечках 3 Багдадом. Водночас, у питанні транспортування вуглеводнів Іракський Курдистан, який не має виходу до моря, опинився у критичній залежності від Туреччини, і це значно обмежує діапазон його опцій у взаєминах з Анкарою. Надмірна залежність економіки Іракського Курдистану від експорту вуглеводнів $\epsilon$ одним зі стратегічних викликів для курдської автономії, проте значні позитивні зрушення у цій сфері можливі лише у досить віддаленій перспективі.

Ключові слова: Ірак, Іракський Курдистан, курдська автономія, Туреччина, нафтогазова галузь.

Oil and natural gas are the main natural resources of the Iraqi Kurdistan. Current estimates of hydrocarbon reserves in the region are different, but in any case it is a huge amount. According to Kurdish officials, the amount of oil deposits in Iraqi Kurdistan is about 45 billion barrels, which is roughly equivalent to stocks of oil-producing countries such as Libya and Nigeria. The gas reserves in the re-

\footnotetext{
${ }^{1}$ Магістр, аспірант кафедри міжнародних відносин та дипломатичної служби факультету міжнародних відносин Львівського національного університету ім. Івана Франка, Україна. E-mail: asoaraz96 @ gmail.com; https://orcid.org/0000-0001-6940-4327.
} 
gion are estimated at about 5.6 trillion cubic meters, that is, they are larger than, for example, in Alge$\mathrm{ria}^{2}$. In addition, in the disputed area of Kirkuk, there are still about 8.7 billion barrels, that is, about a third of all explored oil resources in Iraq (not counting Kurdish autonomy).

The legal basis for the extraction of hydrocarbons in Iraqi Kurdistan was to lay the Iraqi constitution in 2005. Its 108 article states that the country's natural wealth belongs to the entire Iraqi people. Article 109 states that the government manages the extraction of minerals together with regional governments, subject to the equitable distribution of this wealth, and taking into account the population density in the country, with the allocation of temporary additional quotas for the regions affected by the previous regime in order to ensure equal development. At the same time, the key to the development of oil production 112 article is formulated in such a way that leaves room for its excellent interpretation. Such a wording was not accidental; it reflected the differences between the various political forces involved in the drafting of the Iraqi constitution. The first paragraph of article 112 lays responsibility for the extraction of hydrocarbons from existing fields to the federal government, together with the governments of the regions and provinces. It also mentions the need for a pro-rata distribution of incomes from minerals. The second paragraph of the article says that energy policy is being formed jointly by federal, regional and provincial governments.

Specialists point out the lack of specificity, uncertainty in the provisions of the constitution relating to income from extraction of minerals, in particular, the total irregularity of the procedure for obtaining income from the oil and gas industry ${ }^{3}$. The subject of various interpretations of Erbil and Baghdad, regarding which positions of the parties remain different, was, in particular, the provisions of the «existing deposits». The federal authorities have always insisted that the wording of the constitution applies to all fields of oil and gas, and therefore the control over their exploitation should be carried out by the center. Instead, the government of Iraqi Kurdistan believes that the Constitution refers only to the hydrocarbon deposits that were exploited as of August 15, 2005 - the day of completion of the work of constitutional commission ${ }^{4}$. Therefore, according to Erbil, all other fields on the territory of Iraqi Kurdistan should fall within the competence of its government, corresponding to Article 115 of the Constitution, which transfers to the regions all powers that are not specifically reserved as the prerogative of the federal government.

The consequence of the lack of understanding between the Iraqi Kurdistan and the federal center is that Iraq still has no national energy law. The first draft of the federal law on hydrocarbons was developed with the direct participation of Americans. In February 2007, the parliament did not support it due to opposition from opponents of the decentralization of power in Iraq. Later, in July 2007, a new version of the law, which made amendments which increased the powers of the central government, the Kurdish representatives refused even to discuss ${ }^{5}$. In the period between 2007 and 2011, in total three relevant bills were submitted, but all of them were rejected ${ }^{6}$.

Against the backdrop of disagreement with Baghdad, Kurdish autonomy since 2004 has begun to formulate its own energy policy. An important moment in its formation was the introduction, in 2006, in the first time after the civil war, of the united Iraqi Kurdistan government as the Minister of Natural Resources. From May 2006 it holds Ashti Havrami, who representates the Democratic party of Kurdistan, a key figure in the energy sector of Iraqi Kurdistan. The legal basis for the operation of the oil and gas industry in the Kurdistan Region was the local oil and gas law passed in 2007. Its authors proceeded from the right of Iraqi Kurdistan to independently dispose of the oil resources of the region. The law foresees, in particular, the creation of several state-owned companies that would be engaged in geological exploration, extraction and sale on the markets ${ }^{7}$. However, by 2016, only

\footnotetext{
${ }^{2}$ Frappi, C. (2016). The Energy Factor. Oil and State Building in Iraqi Kurdistan, In: Kurdistan. An Invisible Nation. Ed. by Stefano M. Torelli, ISPI, Milano, pp. 97.

${ }^{3}$ Zedalis Rex J. (2009). The Legal Dimension of Oil and Gas in Iraq. Current Reality and Future Prospects, Cambridge University Press, pp. 285-286.

${ }^{4}$ Frappi, C. (2016). The Energy Factor. Oil and State Building in Iraqi Kurdistan, p. 106.

5 Alkadiri Raad. (2010). Oil and the question of federalism in Iraq. In: International Affairs. - Vol. 86. - № 6, Post-American Iraq (November 2010), p. 1320.

${ }^{6}$ Frappi, C. (2016). The Energy Factor. Oil and State Building in Iraqi Kurdistan, p. 107.

${ }^{7}$ Субханкулова Р.P. (2014). О нефтегазовой отрасли Ирака. Научное издание. Москва, с. 60 - 62.
} 
the Kurdish Oil Marketing Organization (KOMO) was established ${ }^{8}$. The Iraqi authorities did not recognize the validity of the Kurdish law.

Being able to ensure a much higher level of security and stability in its territory compared to other regions of Iraq, Erbil began independently, without coordination with Baghdad, to involve foreign companies in the development of oil fields. The first in 2004 was the Norwegian company DNO. The deal signed with it allowed the company to drill near the cities of Zakho and Koysanjak, 70 kilometers from Erbil. It was planned to conduct reconnaissance work for a term of 4 years 9 .

Between 2004 and 2006, the government of Iraqi Kurdistan concluded oil exploration and production agreements with three relatively small companies: the Swiss Addax, the AngloTurkish Genel Energy and Canadian Western Zagros. They concerned work on 7 deposits (blocks) ${ }^{10}$. The standard type of contracts offered to investors was the so-called Production - Sharing Contract, whereby the government and the company received a certain percentage of oil production. For many foreign companies, he proved to be more profitable than the type of contracts offered by the federal authorities of Iraq - the Long-Term Service Contract, which provided for a fixed fee ${ }^{11}$.

Subsequently, the scale investment in the oil industry began to grow. In the period $2007-2008$ years Kurdish authorities negotiated the conclusion of another 20 contracts. Currently, a number of medium-sized companies, have started working on the territory of the autonomy including Hungarians MOL, Austrian OMV, South African KNOC. Better than in the «federal» Iraq situation with security and favorable conditions of agreements were the main arguments of Erbil in talks with investors. Then, after 2011, oil and gas companies of the highest rank entered the Iraqi Kurdistan. The first was «Exxon Mobil», which in November 2011 signed a contract with Erbil to work on 7 blocks ${ }^{12}$. Subsequently, contracts were signed with other «giants»; the total number of oil deals signed by the Kurdish authorities increased to 60 . The result was a huge increase in oil production in the autonomy - from a relatively small 15.7 thousand barrels per day in 2009 to 210 thousand barrels per day in $2015^{13}$.

Among the oil and gas companies that came to Iraqi Kurdistan, there were also Russians. In August 2012, an agreement was signed with the Russian company Gazprom Neft (the "daughter» of Gazprom) which concerned two blocks. In February 2013, it also signed an agreement to develop another block (Halabja). Contracts stipulate that investors will receive $80 \%$ of extraction ${ }^{14}$. Russian investments in exploration in Iraqi Kurdistan by 2015 amounted to 1 billion dollars. For eight years it was planned to get into production at two deposits of 130 thousand barrels of oil per day ${ }^{15}$.

Later, another Russian oil giant, Rosneft, started a deal with Kurdistan Region, which in early 2017 concluded an agreement on cooperation in the field of exploration, extraction, infrastructure, logistics and trading of hydrocarbons with the Iraqi Kurdistan. In particular it provides for the purchase of certain quantities of Kurdish oil by the Russians ${ }^{16}$. Rosneft also cooperates with the federal government of Iraq. In February 2017, this company started work (drilling a search well at the Salman-1 block) in the Arab part of Iraq.

As of 2016, about $98 \%$ of all oil production in the Kurdistan Region was carried out by four major companies - DNO, Genel Energy, British Gulf Keystone and KAR Group. DNO works in the field of Tavka, near the border with Turkey, and the Gulf Keystone develops a field Tak Tak. The KAR Group, the most diversified from all of the companies mentioned here (its activities include oil refining, electricity generation and construction of oil pipelines), is the operator of the Khurmala field, which was developed before the declaration of the autonomy of the Iraqi Kurdistan, and therefore does not fall under the legislation of on new fields. Baghdad does not recognize the right of Erbil to export

\footnotetext{
${ }^{8}$ Frappi, C. (2016). The Energy Factor. Oil and State Building in Iraqi Kurdistan, p. 101.

${ }^{9}$ Старченков Г. (2006). Нефтяная ситуація в Иракском Курдистане. In: Курдский вопрос в Западной Азии в начале XXI века. Сборник статей, Москва, р. 286.

${ }^{10}$ Frappi, C. (2016). The Energy Factor. Oil and State Building in Iraqi Kurdistan, p. 102.

${ }^{11}$ Ibid, p. 102.

${ }^{12}$ Ibid, p. 105.

${ }^{13}$ Ibid, p. 104.

${ }^{14}$ Иванов С.М. (2015). Иракский Курдистан и курдское национальное движение. In: Курдский фактор 8 региональной геополитике (Материаль круглого стола в ИМЭМО РАН 11.03. 2015 г.), с. 13.

15 Там само, с. 13.

16 Роснефть начнет покупать углеводороды в Иракском Курдистане, Available at: http://lenta.ru/news/ 2017/02/21 / rosneft _ Kurdistan/.
} 
the products of Hurmala, but has no opportunity to prevent it. Instead, the authorities in their official reports supply oil extracted from Hurmala as products of the federal North Oil Company ${ }^{17}$.

In the situation of fundamental differences with the federal government concerning the right of Kurdistan Region to conduct an independent operations in the oil and gas industry, a strategic issue for the landlocked autonomy is access to transport infrastructure. For a long time, the main route of oil exports from its territory was the government-controlled Kirkuk-Ceyhan (port in Turkey) oil pipeline built back in 1970. A certain amount of oil could also be transported by tracks through the territory of Turkey or Iran. To reduce its dependence on Baghdad, the oil pipeline from the field was set up in the territory of Iraqi Kurdistan in 2012-2013 to the Turkish border, where it was connected (in Fish Cabour) with the «pipe» Kirkuk - Ceyhan. The new oil pipeline allowed the Kurdish autonomy to end the region's infrastructure isolation, as Erbil had the ability to pump a large quantity of petroleum products without the permission of Baghdad. In 2014, 36.8 thousand barrels per day were pumped through the new pipeline, and in 2015 - 138.6 thousand barrels a day. Another about 4,5 thousand barrels were transported by trucks.

Independent Kurdish activities in the oil and gas industry have become one of the main controversial issues in the relationship between the autonomy and the federal governments of Iraq. The central government has been continually trying to put hydrocarbon production under the control of Baghdad. A sequential guide to this policy for several years was Dr Hussein Shahristani, oil minister in May 2006 - December 2010, and Deputy Head of Iraqi Government from December 2010 to September $2014^{18}$.

It should be noted that the first independent oil deal in the Kurdistan region (the aforementioned agreement with the Norwegians) has provoked a very sharp critique in Iraq. In particular, A. Makee, leader of the Iraqi Islamic Party, said on this occasion: «This is unprecedented. They act as an independent state. This is Iraqi oil, and it will be distributed among all Iraqi people». He also insisted that the actions of the Kurds were a violation of the constitution ${ }^{19}$. In the end, the DNO representatives managed to obtain central government approval for the development of new fields in Iraqi Kurdistan (in fact, oil production at that time was a matter of some perspective, as it was at the beginning of the geological exploration). At the same time, the government insisted that all oil revenues should be distributed at the national level ${ }^{20}$.

The federal government subsequently began to resort to sanctions against companies that entered into agreements with the autonomy. So, in January 2008, Baghdad halted the export of SK Energy (South Korea) and OMV oil. In 2011, the sharp reaction of the federal government caused a contract concluded by the Kurdistan Region with Exxon Mobil; in the end, this led to a reduction in the company's share of the Western Qurna-1 project in southern Iraq. Shortly after protests of the the oil ministry contracts caused signed by the Kurdish regional government with the Russian company Gazprom Neft and with French Total. In particular, in 2012 Baghdad threatened to deprive Gazprom Neft of access to the Badra deposit in the southern part of the country ${ }^{21}$. However, in general, the interests of these companies in the «federal» Iraq are negligible, which reduced the possibility of influence on them by the central government.

In July 2012, the Chevron company, which acquired the right to develop two oil blocks in Iraqi Kurdistan, fell into the government's «black list». However, Chevron does not operate in other parts of Iraq. In general, the result of the pressure of the central government was that, with a few exceptions (Exxon Mobil, Gazprom Neft, Total) companies operating in Iraqi Kurdistan do not conduct works in other regions of Iraq ${ }^{22}$.

In disputes between Baghdad and Erbil on hydrocarbon sides sometimes were able to reach agreement, but it usually turned fragile. For example, in February 2011, the federal government and the autonomy agreed to divide revenues from oil exports from the territory of Iraqi Kurdistan in a proportion

\footnotetext{
${ }^{17}$ Roberts J. (2016). Iraqi Kurdistan Oil and Gas Outlook, Atlantic Council. Global Energy Center and Dinu Patriciu Eurasia Center, p. 19.

${ }^{18}$ Mills R. (2016). Under the Mountains: Kurdish Oil and Regional Politics, OIES Paper: WPM 63, p. 34.

${ }^{19}$ Старченков Г. (2006). Нефтяная ситуація в Иракском Курдистане. In: Курдский вопрос в Западной Азии в начале XXI века. Сборник статей, Москва, с. 286.

${ }^{20}$ Там само, с. 287.

${ }^{21}$ Нефтяной пузырь Курдистана, Available at: https://www.gazeta.ru/business/2016/04/27/8200289.html

${ }^{22}$ Mills R. (2016). Under the Mountains: Kurdish Oil and Regional Politics, OIES Paper: WPM 63, p. 34.
} 
50 to 50. At that moment, Iraqi Prime Minister Nouri al-Maliki even said that Kurdish oil deals would be respected ${ }^{23}$. However, the discrepancies soon began to manifest themselves again. The deteriorating factors for the dialogue were the withdrawal by the end of 2011 of American troops, as this circumstance reduced the possibility of pressure on the part of Americans who always insisted on the need for understanding. In September 2012, Baghdad and Erbil reached a new compromise. However, in November of the same year, the confrontation increased. The reason was the government military operation perceived by the Kurds as an attempt by the center to establish control over the disputed territories. As a result, payments to Erbil were cut off in the Iraqi budget approved in March 2013.

While advocating its position on the production of hydrocarbons, Iraqi Kurdistan resorted to suspending oil exports. In particular, the Kurds did this in September $2011^{24}$. Similarly, Kurdish government officials acted in April 2012 when they stopped the flow of oil through a pipeline controlled by Baghdad. Then Kurdish authorities refered on government debt for the region on the oil yet have beendelivered ${ }^{25}$. The Kurds called the figure of $\$ 1.5$ billion $^{26}$. Oil transportation was restored in July, after the government's pledge to pay autonomy to $\$ 848$ million by September, but in fact, Erbil received only $\$ 550$ million from Baghdad ${ }^{27}$.

In a conflict with the federal center, the Iraqi Kurdistan authorities developed partnerships with Turkey. In November 2013, autonomy entered into an extensive energy deal with Ankara, which also concerned oil and gas exports. Turkish state company received the right to exploit deposits in Iraqi Kurdistan, including in disputed territories. The Turkish side proposed to hold revenue from oil exports through the Turkish state bank, and their subsequent distribution between Erbil and Baghdad through Iraqi state budget - respectively 17 and 83 percent $^{28}$. In practice, this would increase real incomes of the Kurdistan Region, as it freed it from participation in expenditures for federal needs. Baghdad strongly opposed such an option, insisting on its illegality.

Reducing budget payments to Erbil, the federal government at the same time tried to take measures against independent exports of Kurdish oil. An example is the story of a United Kalavryta tanker who was forced to stay at sea near the banks of the state of Texas from June 2014 until January 2015, while lawyers representing the federal government of Iraq argued (meaning oil) that on the ship is the stolen property of the Iraqi government ${ }^{29}$. For their turn, the Kurds tried to transport oil through Israeli ports, transhipped sea cargo from ship to ship, and even used special lure ships to divert attention ${ }^{30}$.

Another aggravation of relations of the federal government and Kurdistan Region in the oil and gas sector was the spring of 2014, on the eve of parliamentary elections on 30 April. After the talks broke out, Baghdad detained budget payments for autonomy in January and February ${ }^{31}$. In the capital, the Kurdish claims were overestimated, once again denying their right to independently export hydrocarbons. The difficult situation of the government of Nuri al-Maliki forced him to take a tough position regarding the demands of the Kurds. In turn, Kurdish leaders resorted to rather sharp rhetoric. In particular, the president of Kurdistan Region Masoud Barzani has compared the threat to cut central government budget payments to the region of the notorious chemical attack in Halabdzhi ${ }^{32}$. The head of

\footnotetext{
${ }^{23}$ Mills R. (2016). Under the Mountains: Kurdish Oil and Regional Politics, OIES Paper: WPM 63, p. 34.

${ }^{24}$ Іракський Курдистан без пояснень перекрив експорт нафти, Available at: http://ukranews. com / ua / news/ 107482- irakskiy - kurdistan.

${ }^{25}$ Іракський Курдистан перекрив багдаду нафтопровід, Available at: http://www. novostimira. com. ua / novyny_18229. html.

${ }^{26}$ Манафова А.Д. (2017). Нефтяная политика Ирака. 2003 - 2016 гг., Москва, Институт Ближнего Востока, с. 75.

${ }^{27}$ Камаран Али Хасан. (2015). Основные факторы и препятствия для развития нефтегазового комплекса Иракского Курдистана In: Науковий вісник Одеського національного економічного університету. Науки: економіка, політологія, історія, № 12 (220), с. 66.

${ }^{28}$ Ottaway D. (2013) Iraq’s Kurdistan Takes a Giant Step Toward Independence. In: Viewpoints. - № 46, p. 3

${ }^{29}$ Mills R. (2016). Under the Mountains: Kurdish Oil and Regional Politics, OIES Paper: WPM 63, p. 36.

${ }^{30}$ Роснефть купит нефть у Иракского Курдистана, Available at: https//www / vedomosti. ru / business / articles / 2017/02/22 / 678692- rosneft.

31 Иракский Курдистан «энергетически» тяготеет к Турции на фоне провала переговоров с Багдадом, Available at: https: // regnum . ru / news / 1793579. html.

32 Нефть рассорила Багдад и Эрбиль перед выборами 30 апреля, Available at: http:// regnum. ru /polit/1789676. html.
} 
the autonomy also talked about the threat of the collapse of the country, and hinted that Iraqi Kurdistan, due to its natural resources, could exist independently.

In September 2014, the government of Heidar Al-Abadi came to power in Baghdad, replacing Nuri Al-Maliki in this post. Both the prime minister and the new oil minister, Adel Abdel Mehdi, have generally taken a more compromise stand on the independent activity of the Kurdish government in the oil and gas sector, than their predecessors. A new attempt was made to reach an agreement between the Kurdistan Region and the federal government in December 2014. According to it Erbil was to receive $17 \%$ of all Iraqi oil revenues, including proceeds from the sale of oil extracted from Iraqi Kurdistan. It was also supposed to finance «Peshmerga» from the federal budget, and instead the government of autonomy has pledged to sell 250,000 barrels of oil a day through the Iraqi state oil marketing organization SOMO. Kurdish officials in connection with the agreement expressed hopes for a long mutually beneficial settlement of the oil dispute with Baghdad ${ }^{33}$. However, the agreements, in the end, have not been fulfilled. In the first half of 2015, the Iraqi government, which received about $\$ 26.7$ billion in hydrocarbon sales, only transferred about $\$ 2$ billion to the Kurdish Autonomy budget, which is less than half what was envisaged by the agreement. As a result, in June 2015, the Kurdish regional government once again resorted to self-selling hydrocarbons, which allowed it to sharply increase its revenues $^{34}$.

In August 2015, the Kyrkuk Provincial Council, which was then controlled by the Kurds, tried to rename the State North Oil Company to the Kirkuk Oil Company, i.e. as if pointing to the potential opportunity to change control over its work. Instead, in March 2016, this company, at the direction of the federal government, suspended (by August of that year) oil exports through the Kirkuk-Ceyhan oil pipeline, thereby reducing the Kurdish regional government's control over export revenues by this strategically important route ${ }^{35}$.

From a technical point of view, oil from the Kurdistan Region can be exported through federal Iraq. But this, obviously, would have made Erbil more dependent on Baghdad. Political and strategic considerations are an obstacle to the development of oil exports through the territory of Iran. Negotiations were held on this, but they did not produce concrete results ${ }^{36}$. Exports through Iran would increase Tehran's influence on Iraqi Kurdistan. Iran has hostile relations with the US, a strategically important partner of the Kurds, and its leadership has always opposed the possible declaration of independence of the Kurdish autonomy.

Starting in 2014, the ISIS attacks in Iraq have become a new factor in the energy policy of the Kurdish autonomy. In the conditions of the war, «Peshmerga» proved to be an important factor in the deterrence of Islamic radicals. At the same time, a sharp drop in oil prices, combined with an increase in military spending, put autonomy in front of very serious budgetary problems. Crisis and US pressure contributed to the conclusion, in November - December 2014, new agreements between government of Iraqi Kurdistan and the federal government, dealing with oil revenue and cost benefits. It was assumed that Erbil will receive from the federal budget 17\% of all income (but minus expenses for general federal needs). Then it would amount to $\$ 1.1$ billion a month. In addition, additional money should be allocated to «Peshmerga». At the same time, autonomy was supposed to export 550 thousand barrels of oil per day, including 250 thousand barrels of Kurdish oil and 300 thousand barrels from the deposits of the Kirkuk district owned by the state, but controlled by the regional government. At that time, the Kirkuk-Ceyhan oil pipeline did not function due to the ISIS, so the only possible way of transporting oil from the Kirkuk region was the aforementioned new oil pipeline. In practice, the deal was not fully executed, and the main contradictions in the oil and gas sector between the autonomy and the federal center did not solve.

Following the start of the ISIS war, a number of international oil companies operating on the territory of the Iraqi Kurdistan began to refuse to conduct search operations. Thus, by the end of 2015, has reduced its activity in this sphere Chevron. By December 2016, another oil giant, Exxon Mobil, stopped working on 3 of the 6 reconnaissance units that had worked previously. In total, it have fired

\footnotetext{
${ }^{33}$ Курдский министр нефти: «Мы поставили перед собой четкие цели самодостаточности», Available at: http: // kurdistan. ru / print / 2014/12/21 / news -23060_Kurdish _ _ ministr _ nefti.

${ }^{34}$ Roberts J. (2016). Iraqi Kurdistan Oil and Gas Outlook, Atlantic Council. Global Energy Center and Dinu Patriciu Eurasia Center, p. 8.

${ }^{35}$ Ibid, p. 23.

${ }^{36}$ Ibid, p. 25.
} 
from 19 reconnaissance units in Iraqi Kurdistan. Experts and officials of the region called various reasons for reducing their activity, but the obvious factor is the loss of the Kurdistan Region of that the level of relative security and stability, which previously contributed to attracting foreign investment in the oil industry of the Kurdish autonomy.

At the same time, the Russian oil giant, Rosneft, plans to expand its, now relatively insignificant, participation in the oil industry of the Iraqi Kurdistan. A set of relevant agreements was signed in June 2017 by head of Iraqi Kurdistan government Nechirvan Barzani, during the International Economic Forum in St. Petersburg. It provided that the Russian company will have access to a regional oil transportation system, and that raw materials from the Iraqi Kurdistan will be delivered to its oil refining capacity in Germany ${ }^{37}$. The above agreements were a continuation and extension of the agreement between the Kurdish government and Rosneft in February 2017. At the same time, in September 2017, another Russian oil company, Gazprom Neft, declared refusing to develop the Halabja block, referring to the difficulty of accessing it deposits, as well as the probability of finding mines in this area ${ }^{38}$.

The lack of understanding between Baghdad and Erbil in the oil and gas industry has led the Iraqi Kurdistan authorities to oppose the agreement made by the OPEC member states on November 30 , 2016. It provided for a reduction, with a view to raising the price of petroleum, its total extraction by the organization's participants by 1.2 million barrels a day. Under the deal, Iraq undertook to cut its oil production by $4.5 \%$. In this regard, the Iraqi minister of oil and gas resources, Jabar al-Laibi, announced at the end of 2016 that Iraqi Kurdistan, as part of Iraq, would also reduce production. Instead, Kurdish officials responded that the decision of the OPEC would only be executed by the Kurdistan Region if the oil deal with Baghdad was reached (which at that time seemed very unlikely) ${ }^{39}$.

In addition to oil deposits, Iraqi Kurdistan has world level gas reserves and has ambitious plans for the development of natural gas production, the main consumer of which should become Turkey. The Turkish gas market is growing rapidly, with the government of that country trying to diversify sources of supply and prevent the monopolization of a strategically important energy sector. Now the prospects for the development of the Kurdish gas sector are associated with Genel Energy. In November, 2015, her chairman said that it hopes that in the early 2020s, Iraqi Kurdistan will supply up to 20 billion cubic meters of gas to Turkey annually ${ }^{40}$.

Note one more aspect of oil and gas industry of Iraqi Kurdistan. It is said that the actual control over the oil and gas sector executes the Democratic Party of Kurdistan and its leader Massoud Barzani, from 2004 to 2017 the President of the Iraqi Kurdistan. Representatives of other Kurdish parties, especially Patriotic Union of Kurdistan and «Gorran», repeatedly criticized the Kurdish government activity, accusing it of opaque awarding contracts and corruption. For example, in April 2016, the representative of "Gorran» stated that over the first three months of this year, regional budget revenues were $\$ 1$ billion higher than expenditures, which raises the question of using this huge difference. But there was no convincing evidence of the existence of a «double accounting» of such scale ${ }^{41}$.

The excessive dependence of the Iraqi Kurdistan oil budget revenues from oil, combined with a similar situation for the whole of Iraq, as well as the war on ISIS, after a sharp fall in oil prices in 2014, triggered a deep and prolonged financial crisis in the Kurdish autonomy. Erbil faces the problem of too much budget deficit. In January 2016, the Minister of the Kurdish Regional Government for Local Self-Government and Tourism, Nivroz Mavlod Amin, said that in 2015, the Kurdistan Region's expenditures amounted to $\$ 12.4$ billion, while revenue was only $\$ 9.5$ billion $^{42}$. Even if the Iraqi Kurdistan managed to increase oil extraction and export from around 600,000 barrels a day to 1 million barrels a day (which, given the reduction in investment, is very problematic), autonomy would still not have been achieved income in the $1-1,2$ billion dollars per month needed to save government spend-

\footnotetext{
${ }^{37}$ Rosneft and the Kurdish Ministry sign a long-term contract on oil and gas, available at: http: // www.rudaw.net /english/kurdistan/020620173

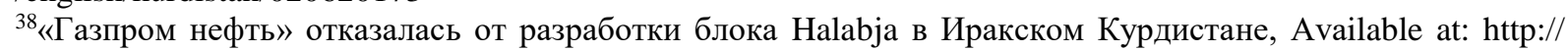
minval. az /news/123725562.

${ }^{39}$ Kurdistan will not cooperate with Iraq on production cuts , Available at: https://www.oilandgas360.com/ kurdistan-will-not-cooperate.

${ }^{40}$ Roberts J. (2016). Iraqi Kurdistan Oil and Gas Outlook, Atlantic Council. Global Energy Center and Dinu

Patriciu Eurasia Center, p. 20.

${ }^{41}$ Ibid, p. 9.

${ }^{42}$ Ibid, p. 3.
} 
ing at the level that was for oil prices of about $\$ 100$, while taking into account the need for a massive government debt service.

In an effort to find a solution, the Kurdish autonomy government began to seek loans from the IMF, the World Bank, the United States and the European Union, rapidly increasing its public debt. Already in December 2014, Erbil's financial commitments to Ankara only amounted to about \$2 billion, and to private lenders about $\$ 1$ billion $^{43}$. Since then, the total debts of the Government of Iraqi Kurdistan have increased significantly. In the fall of oil revenues and fiscal crisis, government of Kurdistan Region, according to some, pondered quite controversial from a legal and political point of view, options for finding a solution to the situation. In December 2016 «WikiLeaks» resource released information ( supposedly a letter to the Minister Ashti Havrami Energy and Natural Resources of Turkey) that Kurds authorities offered to sell to Turkey the rights for Kurdish-controlled oil fields. The total amount of the deal was about $\$ 5$ billion $^{44}$. But the authenticity of these data is difficult to confirm.

Therefore, the crisis forces the Kurdish government to find ways to reform the economy and the budget system. This was announced in April 2016, during a visit to Washington, by Kubad Talabani, Vice Prime Minister of the Iraqi Kurdistan government. It was about measures to reduce public expenditures, reduce the public sector, the government's withdrawal from the fuel and energy sectors of the economy ${ }^{45}$. Today, the ending on Iraq territory the fight against ISIS terrorist groups, creates a more favorable situation for reforms. However, realizing them in life will undoubtedly be very difficult, and real changes are only possible in the long term.

Conclusions. Summarizing the above, we emphasize this. The hydrocarbons, primarily oil, are the main strategic resource of the Iraqi Kurdistan. In an effort to obtain an additional source of income and reduce the level of financial dependence on Baghdad, the regional authorities made efforts to organize their exploitation without the consent of the central government. Investments in Kurdystan Region were contributed by relatively higher level of security than in other regions of Iraq, covered by violence, and more profitable than the federal government proposed conditions of contracts.

Independent actions of Erbil in the oil and gas industry from the very beginning raised objections of the federal authorities, and became one of the central elements of the entire controversial system of relations between the autonomy and the federal center. The lack of a stable solution to the dispute between Baghdad and the Iraqi Kurdistan regarding the exploitation of oil and gas resources is a consequence of the unfinished process of forming a federal state in Iraq, the absence of a full, comprehensive constitutional settlement of the relations between the Kurdish autonomy and the Iraqi state.

Despite a major conflict with Baghdad, the development, based on large-scale foreign investment, of its own oil production in Iraqi Kurdistan was successful. It gave the autonomy a constant source of income, independent of the federal government, against the backdrop of high oil prices contributed to the long-term growth of the region's economy, a positive shift in the living standards of its population. At the same time, Iraqi Kurdistan, without access to the sea, appeared to be rigorously dependent on Turkey for its oil exports, which has not only economic but also political dimensions. In particular, this dependence is a factor that reduces the ability of the Iraqi Kurds to show solidarity with the Kurds in Turkey. Furthermore, despite the relatively successful development of various sectors of industry and agriculture, «quick» oil revenues led to the formation of the vulnerable resource economy, and the fall in hydrocarbon prices in 2014 immediately found itself in crisis. Today, Iraqi Kurdistan is faced with the strategic challenge of seeking a model of economic development that would reduce its economic and political dependence on the state of affairs in the oil and gas sector. However, this, obviously, is only possible in the long term and in conditions of political stability and security in the region.

\section{Список джерел}

\footnotetext{
${ }^{43}$ Roberts J. (2016). Op. cit., p. 10.

${ }^{44}$ Documents reveal Iraqi Kurdistan attempts to sell oil fields to Turkey, Available at: http://ekurd.net/kurdistan sell-oil-fields-turkey-2016-12-27.

${ }^{45}$ Roberts J. (2016). Op. cit., p. 27.
} 
1. «Газпром нефть» отказалась от разработки блока Halabja в Иракском Курдистане, Available at: http://minval.az/news/123725562/.

2. Иванов С.М. (2015). Иракский Курдистан и курдское национальное движение. In: Курдский фактор в региональной геополитике (Материаль круглого стола в ИМЭМО РАН 11.03. 2015 г.). - Рp. 6-20.

3. Іракський Курдистан без пояснень припинив експорт нафти, Available at: https: // ukranews.com/ua/news/107482-irakskiy-kurdistan.

4. Іракський Курдистан перекрив Багдаду нафтопровід, Available at: http://www. novostimira.com.ua/novyny_18229.html.

5. Иракский Курдистан «энергетически» тяготеет к Турции на фоне провала переговоров с Багдадом, Available at: https://regnum.ru/news/1793579.html.

6. Камаран Али Хасан. (2015). Основные факторы и препятствия для развития нефтегазового комплекса Иракского Курдистана In: Науковий вісник Одеського національного економічного університету. - Науки: економіка, політологія, історія, № 12 (220). - Рp. 62-71.

7. Курдский министр нефти: «Мы поставили перед собой четкие цели самодостаточности», Available at: http://kurdistan.ru/print/2014/12/21/news-23060_Kurdskiy_ministr_nefti.

8. Манафова А.Д. (2017). Нефтяная политика Ирака. 2003 - 2016 гг., Москва, Институт Ближнего Востока.

9. Нефтяной пузырь Курдистана, Available at: // www.gaxeta.ru/business/2016/04/27/82002 89.html.

10. Нефть рассорила Багдад и Эрбиль перед выборами 30 апреля, Available at: https: // regnum.ru/polit/1789676.html.

11. «Роснефть» купит нефть у Иракского Курдистана, Available at: https:www/vedomosti.ru /business/articles/2017/02/22/678692-rosneft.

12. Роснефть начнет покупать углеводороды в Иракском Курдистане, Available at: https://lenta.ru/news/2017/02/21/rosneft_Kurdistan.

13. Старченков Г. (2006). Нефтяная ситуація в Иракском Курдистане. In: Курдский вопрос в Западной Азии в начале ХХІ века. Сборник статей, Москва, Рp. 279-289.

14. Субханкулова Р.Р. (2014). О нефтегазовой отрасли Ирака. Научное издание. Москва.

15. Alkadiri Raad. (2010). Oil and the question of federalism in Iraq. In: International Affairs. Vol. 86. - № 6, Post-American Iraq (November 2010), pp. 1315-1328.

16. Documents reveal Iraqi Kurdistan attempts to sell oil fields to Turkey, Available at: http://ekurd.net/kurdistan-sell-oil-fields-turkey-2016-12-27.

17. Frappi, C. (2016). The Energy Factor. Oil and State Building in Iraqi Kurdistan, In: Kurdistan. An Invisible Nation. Ed. by Stefano M. Torelli, ISPI, Milano, pp. 91-121.

18. Kurdistan will not cooperate with Iraq on production cuts, Available at: https:// www.oilandgas360.com/kurdistan-will-not-cooperate... 63.

19. Mills R. (2016). Under the Mountains: Kurdish Oil and Regional Politics, OIES Paper: WPM

20. Ottaway D. (2013) Iraq's Kurdistan Takes a Giant Step Toward Independence. In: Viewpoints. - № 46.

21. Roberts J. (2016). Iraqi Kurdistan Oil and Gas Outlook, Atlantic Council. Global Energy Center and Dinu Patriciu Eurasia Center.

22. Rosneft and Kurdish ministry sign long-term contract on oil and gas, Available at: http:// www.rudaw.net/english/kurdistan/020620173.

23. Zedalis Rex J. (2009). The Legal Dimension of Oil and Gas in Iraq. Current Reality and Future Prospects, Cambridge University Press.

\section{References}

1. «Hazprom neft'» otkazalas' ot razrabotky bloka Halabja v Yrakskom Kurdystane, Available at: http://minval.az/news/123725562.

2. Yvanov S.M. (2015). Yrakskyy Kurdystan y kurdskoe natsyonal'noe dvyzhenye. In: Kurdskyy faktor v rehyonal'noy heopolytyke (Materyaly kruhloho stola v YMÉMO RAN 11.03. 2015 h.). - Pp. 620. 
3. Iraks'kyy Kurdystan bez poyasnen' prypynyv eksport nafty, Available at: https://ukranews.com /ua/news/107482-irakskiy-kurdistan.

4. Iraks'kyy Kurdystan perekryv Bahdadu naftoprovid, Available at: http: //www.novostimira.com.ua/novyny_18229.html.

5. Yrakskyy Kurdystan «énerhetychesky» tyahoteet k Turtsyy na fone provala perehovorov s Bahdadom, Available at: https://regnum.ru/news/1793579.html.

6. Kamaran Aly Khasan. (2015). Osnovnye faktory y prepyat.stvyya dlya razvytyya neftehazovoho kompleksa Yrakskoho Kurdystana In: Naukovyy visnyk Odes'koho natsional'noho ekonomichnoho universytetu. - Nauky: ekonomika, politolohiya, istoriya, № 12 (220). - Pp. 62-71.

7. Kurdskyy mynystr nefty: «My postavyly pered soboy chetkye tsely samodostatochnosty», Available at: http://kurdistan.ru/print/2014/12/21/news-23060_Kurdskiy_ministr_nefti.

8. Manafova A.D. (2017). Neftyanaya polytyka Yraka. 2003 - 2016 hh., Moskva, Ynstytut Blyzhneho Vostoka.

9. Neftyanoy puzyr' Kurdystana, Available at: // www.gaxeta.ru/business/ 2016/04/27/82002 89.html.

10. Neft' rassoryla Bahdad y Érbyl' pered vyboramy 30 aprelya, Available at: https://regnum.ru/ polit/ 1789676.html.

11. «Rosneft'» kupyt neft' u Yrakskoho Kurdystana, Available at: https: www/vedomosti.ru/business/articles/2017/02/22/678692-rosneft.

12. Rosneft' nachnet pokupat' uhlevodorody $\mathrm{v}$ Yrakskom Kurdystane, Available at: https://lenta.ru/news/2017/02/21/rosneft_Kurdistan.

13. Starchenkov H. (2006). Neftyanaya sytuatsiya v Yrakskom Kurdystane. In: Kurdskyy vopros $v$ Zapadnoy Azyy v nachale XXI veka. Sbornyk statey, Moskva, Pp. 279 - 289.

14. Subkhankulova R.R. (2014). O neftehazovoy otrasly Yraka. Nauchnoe yzdanye. Moskva.

15. Alkadiri Raad. (2010). Oil and the question of federalism in Iraq. In: International Affairs. Vol. 86. - № 6, Post-American Iraq (November 2010), pp. 1315-1328.

16. Documents reveal Iraqi Kurdistan attempts to sell oil fields to Turkey, Available at: http://ekurd.net/kurdistan-sell-oil-fields-turkey-2016-12-27.

17. Frappi, C. (2016). The Energy Factor. Oil and State Building in Iraqi Kurdistan, In: Kurdistan. An Invisible Nation. Ed. by Stefano M. Torelli, ISPI, Milano, pp. 91-121.

18. Kurdistan will not cooperate with Iraq on production cuts, Available at: https:// www.oilandgas360.com/kurdistan-will-not-cooperate.

19. Mills R. (2016). Under the Mountains: Kurdish Oil and Regional Politics, OIES Paper: WPM 63.

20. Ottaway D. (2013) Iraq's Kurdistan Takes a Giant Step Toward Independence. In: Viewpoints. - № 46.

21. Roberts J. (2016). Iraqi Kurdistan Oil and Gas Outlook, Atlantic Council. Global Energy Center and Dinu Patriciu Eurasia Center.

22. Rosneft and Kurdish ministry sign long-term contract on oil and gas, Available at: http://www. rudaw.net/english/kurdistan/020620173.

23. Zedalis Rex J. (2009). The Legal Dimension of Oil and Gas in Iraq. Current Reality and Future Prospects, Cambridge University Press. 